\title{
Visit to a Tiger Reserve
}

\section{Anne Wright}

A Trustee of the Indian World Wildlife Fund Appeal, the author has been closely connected with the conservation of the tiger. She describes the Sundarbans tiger reserve where some tigers are man-eaters. Mrs Wright was also involved in the incident in 1974, described in the following article, when a tiger that had killed a woman was translocated from an inhabited area to the reserve - the first time this had been done - in an attempt to save it.

For those of us who live in West Bengal, the Sundarbans, a unique estuarine swamp forest with a myriad of mangrove islands at the mouth of the Ganges, is the tiger reserve with which we are most closely linked. The preservation of these hauntingly beautiful wetlands is of the greatest importance, for they act as a buffer zone to protect the farmland behind from cyclones and tidal waves sweeping in from the Bay of Bengal. It is sometimes difficult for even politicians and officials to realise that if the Sundarbans are reduced and settled the local people will be the first to suffer. Since 1876 the area has been protected forest, but in fact much land has been cleared and taken over by cultivators. The remaining forest now covers $4262 \mathrm{sq}$. $\mathrm{km}$., with no villages or agricultural land. The islands are inaccessible and unsuitable for cultivation, with no drinking water apart from one or two man-made water tanks. Visiting fishermen and forest staff have to take water in earthenware pots on their boats.

The entire Ganges delta is criss-crossed by large rivers and innumerable creeks and channels, and the tigers and other wildlife have become marvellously adapted to an amphibious way of life. They live in an entirely saline environment and have to cope with continuous tides and numerous cyclones. Javan rhinoceros have long since disappeared from the islands, as have swamp deer, wild buffalo, and, more recently, barking deer. The tigers now live on wild pig and axis deer, both fairly common, supplemented by monkeys, monitor lizards, crabs and, sometimes, man. An accurate record of numbers is impossible in the dense swamps; 27 . were recorded in a recent census in a limited area. Twenty years ago the estuarine crocodile Crocodylus porosus, one of the largest crocodiles in the world, was common; it is now rare due to heavy poaching. The fishing cat Felis viverrina, about which almost nothing is known, is on the islands, and another endangered species, the very large water or ringed lizard Varanus salvator, is occasionally seen. Altogether about thirtyfive species of mammals live in the delta area.

I revisted the Sundarbans with Peter Jackson, WWF Director of Information, who was in India to discuss equipment for Project Tiger, on board the Forest Department launch Bonashree. Our host was Mr Das, Conservator of Forests, West Bengal Forest Department, and Field Director of the Sundarbans Tiger Reserve. Steaming downstream we passed boats laden with wood moving slowly upstream. The Sundarban islands are divided into forest blocks which are worked as coups for timber felling. The boats or flats are pulled by smaller craft with teams of men rowing rhythmically, like oarsmen on ancient galleys. The contracts for wood collection are sold by the Forest Department in the form of permits, and royalties are issued by the size of the 
boatloads, assessed by the boats' high-water marks. The main woods are baen Avicennia marina, goran Ceriops candolleana, keora Sonnertia apetala, and gengwa Exacaecaria agallocha. Goran is used for building and fire-wood; gengwa is used for packing and match boxes, and is now also in great demand for paper pulp. Under the Tiger Reserve plan an area of $1330 \mathrm{sq} . \mathrm{km}$. will be kept clear of felling, and the collecting of minor forest produce, such as honey and shells, banned. (Shells are collected and sold for making calcium carbonate, used in 'pan' and whitewash.)

Going ashore was a hazardous performance whether from the tiger or from our faithful guards, who were very much on the alert, peering cautiously under the low bushes - the tiger is held in great respect. One tended to be looking down the barrel of a gun every time one looked round.

At Bagmara Block we reached the heart of the Tiger Reserve and came to the open sea. Mud banks had given away to wide beaches, and, wading ashore, we walked on golden sand embroidered with patterns made by the thousands of blood-red crabs that ventured out of their holes in little rushes to throw sand at each other. Following the pugmarks of a large male tiger we came on a herd of twenty axis deer, with one or two good heads among them, grazing peacefully on a patch of grass. Fresh pugmarks in the sand showed where our tiger had been joined by a tigress with a cub.

Sailing back through the islands we heard the twittering trill of whimbrel, the plaintive cry of stone curlew, and the sharp call of rose-ringed parakeets; we saw a pair of great stone plover by a herd of axis deer and a lesser adjutant stork catching crabs. Crossing to Dalhousie Island we saw 45 different species, mostly waders, but including a white-bellied sea eagle soaring overhead. Most exciting was a goliath heron, a bird that has not been reported since 1925, when it was seen in the Khulna area several hundred miles to the north-east.

Steaming northwards again we passed a boat apparently off course. Questioned by the Forest Department guards the sarang explained that the day before a tiger had carried off four men working in a felling coup to the north. The description was lurid, and in retrospect one was glad that our faithful guards had covered our every movement ashore.

The reserve has come in the nick of time to save the wildlife of this unspoilt delta. The remoteness and inaccessibility of the Sundarbans, except by boat, has saved them from development, but for the same reasons the wildlife has suffered, for it is difficult to patrol the borders, and the Sundarbans have long been the haunt of smugglers and dacoits. Poaching of deer, pig, tiger and crocodiles has been serious. But lack of sweet water, and perhaps the tigers themselves, have kept people away.

The West Bengal Government are moving ahead with the Tiger Project, but a real impact will not be felt until the Department has boats and rapid communications to implement and enforce the plan.

\section{Field Worker Wanted in Malaysia}

John Brian Payne would like an assistant with either academic or field experience to work with him on the ecology of frugivores in Malaysian forest for at least six months between March.1976 and September 1977. Food, accommodation and local transport provided: Sub-Department of Veterinary Anatomy, University of Cambridge, Tennis Court Road, Cambridge CB2 1QS. 